\title{
MCH Basel Exhibition Ltd.: First Test of the New Exhibitions $r+d$ in life sciences and REACH for process solutions*
}

\author{
Keywords: $\mathrm{MCH}$ Basel Exhibition Ltd. $\cdot r+d$ in life sciences · REACH for process solutions · \\ Swiss exhibition - Trade fairs
}

On Friday 18 October 2002 the new trade fairs $r+d$ in life sciences and REACH for process solutions closed their doors in Basel Exhibition. During a four-day period 14,200 trade visitors toured the two exhibitions. $r+d$ in life sciences - the international trade fair and congress for research and development, analytics and diagnostics in life sciences and the chemical industry - featured presentations by 304 exhibitors. REACH for process solutions - the international trade fair for processes, process technology and environment management - numbered a total of 289 exhibitors.

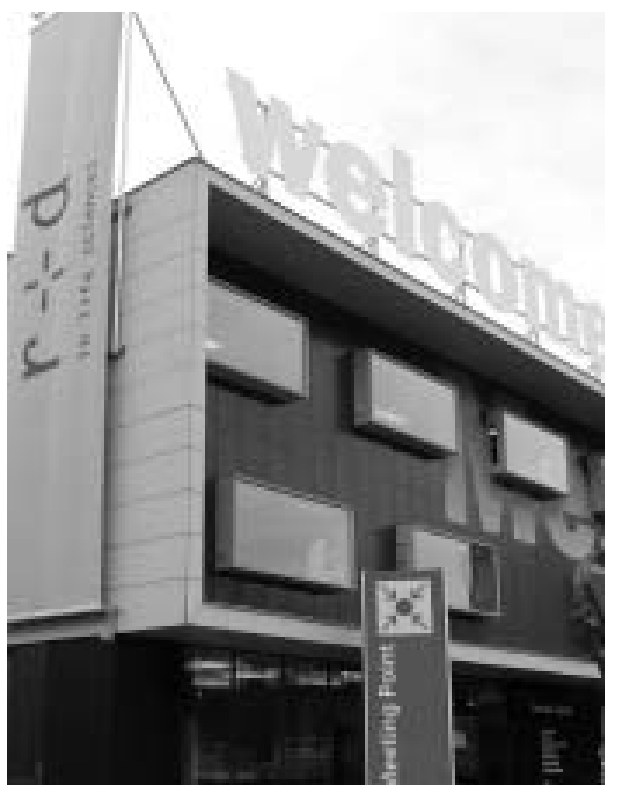

${ }^{*}$ Contact: Robert Appel

Project Manager $r+d$ in life sciences

$\mathrm{MCH}$ Basel Exhibition Ltd.

P.O.Box

$\mathrm{CH}-4021$ Basel

Tel.: +4158206 2370

Fax: +41582062189

E-Mail: robert.appel@messe.ch
At the inaugural edition of $r+d$ in life sciences and REACH for process solutions, the organizer Swiss Exhibition, attracted a total of 14,200 trade visitors. A quarter of the visitors to each of these fairs came from abroad. The trade visitors were of high quality, with about two-thirds in each case having total or partial responsibility for decisions to purchase.

After a restrained start, attendance developed well in the course of the trade fairs even though they did not quite live up to the hopes of the organizer and its exhibitors. Initial statements made by numerous exhibitors reported a general trend in which fewer - albeit more competent - visitors called on their stands. Apart from the great professional expertise of the visitors to both fairs, exhibitors primarily praised the synergies created between the two events.

The names of the precursor fairs ilmac and M.U.T. - are still firmly anchored in the minds of many exhibitors and visitors. $r+d$ in life sciences and $\mathrm{REACH}$ for process solutions, being two new products, need time to find their feet. This was said to be more difficult, since the current economic situation does little to generate a positive climate for business.

\section{Congress: $\mathbf{r + d}$ in life sciences 2002}

The $r+d$ in life sciences congress was attended by a total of 1,517 participants. The congress, $r+d$ in life sciences, took place in parallel to the trade fair and covered the topics analytics, biotechnology, chemistry and spectrometry. In so doing, it supplemented the themes addressed by the fair by adding a scientific dimension.
About 800 members attended the fall meeting of the SCG (Swiss Chemical Society) held within the congress. Two prizes were awarded in conjunction with the opening. The Werner Prize, worth 10,000 Swiss francs, went to two young scientists of the new generation, Prof. Dr. Jérôme Lacour of the University of Geneva and Prof. Dr. Werner Nau of the University of Basel. The Paracelsus Prize, which comes with 20,000 Swiss francs in prize money, was awarded to Prof. Martin Quack of the Laboratory of Physical Chemistry of ETH Zürich.

\section{CryoWorld 2002 at REACH for process solutions}

Low temperature technology cryogenics - received its first significant platform in Europe with the Cryo World feature at REACH for process solutions. This was an ideal supplement to the industrial processes and process technology on show. The impact of CryoWorld was enhanced by the professional lectures presented at the CryoForum.

\section{REACH Congress 2002}

The REACH Congress attracted a total of 550 participants who were full of praise for the breadth of its scope and for its high quality. In this respect, the congress focused quite clearly on environmental issues, with great interest also being shown in the papers on work safety.

\section{REACH 2002 Environment Prize}

During the opening day of $\mathrm{REACH}$ for process solutions, the Environment Prize of the "Pro Aqua - Pro Vita» Foundation, worth 50,000 Swiss 
francs, was presented to Philipp Widmer of $\mathrm{eCO}_{2} \mathrm{SA}$ for a new cleansing process using supercritical carbon dioxide.

The next REACH for process solutions is planned from 12 to 15 October 2004.

The next $r+d$ in life sciences is scheduled for 24 to 27 May 2005.

\section{Statements Made by Exhibitors Regarding the Trade Fairs}

\section{Views on $r+d$ in life sciences}

\section{Hansruedi Merz,}

Sales Manager Switzerland,

Büchi Labortechnik AG:

My overall impression is positive, despite fewer visitors. This is above all thanks to the larger influx of visitors on the second and third days. The quality of these visitors is gratifying, too. I also consider the parallel running of the trade fair for processes and process technology - REACH for process solutions - to be beneficial and important, since it extends the overall selection on show.

\section{Andreas Hedinger, \\ Managing Director, \\ Leica Microsystems (Schweiz) AG:}

We were satisfied with the quality of our visitors, but not yet with their quantity. We think that one reason for the modest attendance was that many visitors failed to grasp the transition from ilmac to $r+d$. The name «ilmac» is still anchored in people's minds and the new name, « $r+d$ in life sciences» still has to sink in.

\section{Giulio Pè,}

Manager Business

Processes Laboratory,

Mettler-Toledo (Schweiz) AG:

By and large we consider our involvement in the fair to have been satisfactory. It was most gratifying that many of our regular customers approached us with new projects. We also consider it positive that discussions remained on a consistently high level and that visitor frequency rose towards the middle of the week.

\section{Marcel Schönmann, \\ Sales Manager, \\ Varian AG:}

We are satisfied with our participation in $r+d$ in life sciences. In particular, the quality of the enquiries received on days two and three of the fair was encouraging. It was, moreover, gratifying that many visitors to our stand came from the universities since we consider it important to have a wide variety of visitors. The difficult economic climate did, however, have a direct influence on attendance. The new exhibition concept is appropriate, as is its name, although the title $-r+d$ in life sciences is regrettably insufficiently known within the trade at present.

\section{Views on REACH for process solutions}

\section{Andreas Wiedmer,}

Manager,

FZN Umwelttechnik AG:

Although attendance was noticeably below that at M.U.T., it did come from new business sectors. In this respect the new concept proved effective. I am not satisfied with the periodicity of the fair: although a three-year cycle is planned, this and the next event have been scheduled after just two years. And every two years is too close together: the three-year rhythm would be perfect.

\section{Markus Maurer,}

Marketing Communication Manager, Rittmeyer AG:

We have been present at M.U.T. for years, but decided at an early stage to take part in REACH. For us, this is a question of image. REACH is currently the only fair in Switzerland for the water/wastewater sector. We were, of course, rather disappointed by the number of visitors. However, a good Thursday made up for the weak start. For us, a trade fair is a place for cultivating our contact with customers, and this we were able to do. In future, events such as the Brunnenmeister Tagung (the meeting of master wellkeepers) should be better integrated within the fair. This fair quite definitely has potential.

\section{Jürg Schudel, \\ Manager, \\ schudel ag:}

We really jumped in at the deep end with our involvement in this fair. We had never been represented in Basel before and tried to set ourselves realistic goals for a newly launched trade fair. Our customers were, however, pleased that we were taking part and even customers from western Switzerland came to see us in Basel. We were also able to make totally new contacts. It remains to be seen what the ROI will be. We were certainly heartened by the quality of the discussions we had: visitors came to see us with specific questions, expecting us to produce specific solutions. It was good that we took part at this fair.

\section{Views on CryoWorld}

\section{Natalie K. Moore,}

Global Marketing Manager,

Air Products and Chemicals, Inc.:

There is clearly a need for an independent and international platform for the cryogenics industry, so CryoWorld is a step in the right direction. We have made some good contacts for future opportunities. You have to give it a chance to develop.

\section{Carlo Vercelli,}

Marketing \& Sales Manager,

Sauerstoffwerk

Lenzburg AG - SL GAS:

CryoWorld, integrated within REACH, is the perfect platform for our cryogenic equipment and, quite generally, for demonstrating our gas know-how to existing and potential customers. Very many qualified visitors called on our stand, including those from the parallel event, $r+d$ in life sciences. CryoWorld should certainly be expanded since there is no similar fair in Europe for our field of activities.

\section{The Winners of the REACH 2002 Environment Prize}

\section{Philipp Widmer, \\ President, eCO2 SA:}

We were, of course, delighted to receive the Environment Prize. It is important as a springboard for two separate reasons. Firstly, it gives us publicity and makes the general public aware of us, but secondly it is a kind of seal of quality. To be assessed by an independent jury of experts and to receive the prize is important for us, for example during future discussions with investors. The prize now enables us to embark on long-planned activities and thus to continue the development of our company. 